\title{
Effects of mannan oligosaccharides on growth performance, nutrient digestibility, ruminal fermentation, and hematological parameters in sheep
}

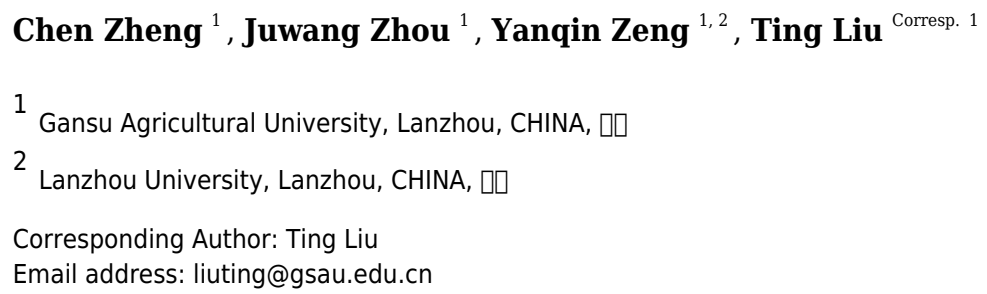

Background. Mannan oligosaccharides (MOS) are a promising feed additive in animal husbandry due to mainly improving animal health status. The purpose of this study was to investigate the effects of MOS on growth performance, nutrient digestibility, ruminal fermentation, and twelve hematological parameters in sheep. Methods. Ninety-six healthy Hu rams with similar body weights were chosen and divided into four treatment groups (twenty-four rams in each group), in which four different doses of MOS were tested: $0,0.8,1.6$, and $2.4 \%$ of the basal diet (on an as-fed basis). Results. The results showed that supplementation dietary MOS did not affect feed intake, body weight, average daily weight gain, or ruminal short-chain fatty acids (SCFAs) concentration; the ratio of individual fatty acids to total SCFAs, the $\mathrm{C} 2 / \mathrm{C} 3$ ratio, and the hematological parameters in the sheep were also unaltered $(P>0.05)$. Conversely, supplementation dietary MOS increased the dry matter, organic matter, crude protein, neutral detergent fiber, acid detergent fiber, and ash apparent digestibility $(P<0.05)$, and decreased the ruminal ammonia concentration in the sheep $(P<0.05)$, especially at a dose of $1.6 \%$.

Conclusions. This indicates that supplementation dietary MOS improved nutrient utilization by the sheep and nitrogen metabolism in the rumen; however, the effects are too slight to interfere with the basal metabolism in the sheep. 
1 Effects of mannan oligosaccharides on growth performance, 2 nutrient digestibility, ruminal fermentation, and 3 hematological parameters in sheep

${ }^{1}$ College of Animal Science and Technology, Gansu Agricultural University, Lanzhou 730070,

9 Gansu Province, P. R. China

Corresponding Author:

13 Ting Liu ${ }^{1}$

No.1 Yingmen Village, Anning District, Lanzhou, Gansu Province, 730070, P. R. China 
42 Abstract

43 Background. Mannan oligosaccharides (MOS) are a promising feed additive in animal husbandry

44 due to mainly improving animal health status. The purpose of this study was to investigate the 45 effects of MOS on growth performance, nutrient digestibility, ruminal fermentation, and twelve 46 hematological parameters in sheep.

47 Methods. Ninety-six healthy $H u$ rams with similar body weights were chosen and divided into 48 four treatment groups (twenty-four rams in each group), in which four different doses of MOS 49 were tested: $0,0.8,1.6$, and $2.4 \%$ of the basal diet (on an as-fed basis).

50 Results. The results showed that supplementation dietary MOS did not affect feed intake, body 51 weight, average daily weight gain, or ruminal short-chain fatty acids (SCFAs) concentration; the 52 ratio of individual fatty acids to total SCFAs, the $\mathrm{C} 2 / \mathrm{C} 3$ ratio, and the hematological parameters 53 in the sheep were also unaltered $(P>0.05)$. Conversely, supplementation dietary MOS increased 54 the dry matter, organic matter, crude protein, neutral detergent fiber, acid detergent fiber, and ash 55 $56(P<0.05)$, especially at a dose of $1.6 \%$.

57 Conclusions. This indicates that supplementation dietary MOS improved nutrient utilization by 58 the sheep and nitrogen metabolism in the rumen; however, the effects are too slight to interfere 59 with the basal metabolism in the sheep.

60

61

62

Keywords: digestibility, growth performance, mannan oligosaccharides, ruminal fermentation,

63

64

65

66

67

68

69

70

71

72

73

74

75

76

77

78

79

80

81

PeerJ reviewing PDF | (2021:01:56977:3:0:NEW 21 May 2021) 


\section{Introduction}

83 In sheep industry, the sheep should be fed by balance diets which contained all kinds of nutrients

84

85

86

87

88

89

90

91

92

93

94

95

96

97

98

99

100

101

102

103

104

105

106

107

108

109

110

111

112

113

114

115

116

117

118

119

120

121 even some small feed additives to improve nutrients digestion and absorption, promote ruminal fermentation and hematological parameters, ultimately enhance the growth performance and productivity of sheep. It is well known that more nutrients are digested and absorbed, better ruminal fermentation is established, and healthier body status including hematological parameters is formed, will lead to higher growth performance and productivity in sheep.

The use of functional feed ingredients, such as probiotics, prebiotics, and immunostimulants, to improve species growth and product quality without harming the environment has recently become widespread. Prebiotics are good examples of food supplements that improve animals' growth performance and benefit animals' health by modulating gastrointestinal tract microbiota, such as providing energy for favorable endogenous bacteria and reducing enumeration of pathogenic intestinal bacteria (Abd El-Hack et al., 2021).

Mannan oligosaccharides (MOS) are structural cell wall components of Saccharomyces cerevisiae (Van den Abbeele et al., 2020). In monogastric animals, supplementation dietary MOS brought uplifting effects including improvement growth performance and nutrients digestion, promotion health status, boosting gastrointestinal tract morphological integrity, enhancement antioxidant capacity, facilitation immunological status, upregulation immune related gene expression (Ren et al., 2020; Van den Abbeele et al., 2020; Zhou et al., 2020).

Because of special physiological feature and gastrointestinal tract structure, fewer researches focused on the effects of MOS on ruminants due to a principle widely accepted that ruminal microbe degraded oligosaccharides and weakened their activity (Zheng et al., 2018). In fact, however, supplementation dietary MOS has been confirmed that they benefited their ruminal hosts. In beef cattle and dairy cows, supplementation dietary MOS maintained more body weight of beef cows during parturition (Linneen et al., 2014), produced significantly more colostrum of dairy cows (Westland et al., 2017), enhanced immune response to rotavirus of dairy cows during the dry period and tended to enhance the subsequent transfer of rotavirus antibodies to their calves (Franklin et al., 2005). In sheep, supplementation dietary MOS increased ruminal $\mathrm{pH}$ and total short chain fatty acids (SCFAs) concentration, decreased lipopolysaccharides (LPS) level in plasma, reduced ruminal ammonia concentration and ruminal stratum corneum thickness and total thickness of ruminal epithelium, as well as the incidence and severity of hepatic abscesses (Diaz et al., 2018). In our previous studies, similarly, supplementation dietary MOS increased antioxidant capacity (Zheng et al., 2018) and crude protein (CP) retention rate and decreased energy release as methane $\left(\mathrm{CH}_{4}\right)$ in sheep (Zheng et al., 2019).

Nevertheless, many previous studies, including our previous studies, have been carried out under experimental feeding conditions in laboratories; thus, the actual breeding effects of MOS on sheep under practical production conditions still need be revealed. In addition, based on these aforementioned achievements, such as supplementation dietary MOS improved CP and energy utilization in sheep and maintained well healthy and production status in cattle under laboratories conditions, we hypothesized that supplementation dietary MOS could improve productivity and 
122 nutrient utilization in sheep under actual farm condition, and sought to determine changes in

123

124

125

126

127

128

129

130

131

132

133

134

135

136

137

138

139

140

141

142

143

144

145

146

147

148

149

150

151

152

153

154

155

156

157

158

159

160

161

several hematological parameters in sheep because of insufficient evidence provided by hematological parameters. Therefore, this study examined growth performance, apparent nutrient digestibility, ruminal fermentation, and some hematological parameters in sheep fed MOS to provide evidences supporting the actual breeding application of MOS in ruminants' feed.

\section{Materials \& Methods}

All experiments in this study were carried out in accordance with the approved guidelines of the Regulation Standing Committee of Gansu People's Congress. All experimental protocols and sample collection were approved by the Ethics Committee of Gansu Agriculture University under permission no. GAU-LC-2020-018.

\section{Schematic overview of the experimental program}

The experiments included sheep feeding trial and samples laboratory analysis. The sheep were fed for 7 weeks, the feed intake and growth performance were recorded, and the feces, urine, ruminal fluid, and blood samples were collected during the feeding trial. The blood samples were analyzed by a fully automatic hematology analyzer immediately after collecting. Then, the other samples were taken back to laboratory to analyze the nutrients concentration and ruminal fermentation parameters.

Please place Figure 1 here.

\section{Experimental design, animals, and housing}

A single-factor design was used for this experiment. Four different doses of MOS (SCIPHAR ${ }^{\circledR}$; Sciphar, Inc., Xi'an, Shaanxi, P. R. China) were tested: 0, 0.8, 1.6, and 2.4\% of basal diet (on an as-fed basis). Ninety-six healthy $H u$ rams with similar body weights $(31.11 \pm 2.69 \mathrm{~kg})$ were chosen and divided into four treatment groups. Each group had twenty-four rams. The test period included a 2-week acclimation period and a 5-week feeding trial (including a 6-day digestion and metabolism experiment during the fourth week). All rams were loose-housed in $10 \mathrm{~m}^{2}$ barns and $20 \mathrm{~m}^{2}$ yards according to experimental design. Each loose-housing system was equipped with a feeder and a drinker, providing ad libitum access to feed and water.

During the feeding trial, the weights of feed intake and residues were carefully recorded daily in each replicate, and body weights were recorded weekly before the morning feeding.

\section{Experimental diets}

Four isoenergetic and isonitrogenous diets were formulated to meet or exceed nutrient recommendations for rams according to the China Agricultural Industry Standard (NY/T8162004). Feedstuff's compositions were adjusted to create four experimental diets containing different levels of MOS but the same nutrient compositions (Table 1).

Please place Table 1 here.

\section{Sample collection and analysis}

\section{Feed, feces and urine samples collection and preparation}

During the third and fourth weeks, the digestion and metabolism experiment was carried out (Costa et al., 2021; Sinz et al., 2021). Six sheep was randomly chosen from each treatment, and the 24 chosen sheep were transferred into individual digestion and metabolism cages. After a 6-

Peer) reviewing PDF | (2021:01:56977:3:0:NEW 21 May 2021) 
162 day acclimation period, $10 \%$ of the total feed, $10 \%$ of the total feces output, and $5 \%$ of the total

163

164

165

166

167

168

169

170

171

172

173

174

175

176

177

178

179

180

181

182

183

184

185

186

187

188

189

190

191

192

193

194

195

196

197

198

199

200

201

urine output ( $5 \mathrm{~mL}$ sulfuric acid was added to the collection bowl to prevent nitrogen release before collection) were sampled daily for 6 days and stored at $-20^{\circ} \mathrm{C}$ (Zheng et al., 2018). For nitrogen analysis, samples of $3 \%$ of the total feces output were taken daily, stored in wide-mouth

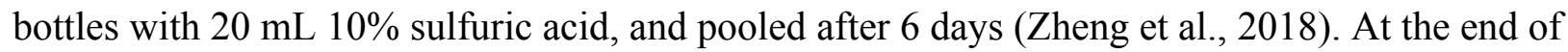
the data collection period, feed and fecal samples were thawed and pooled for each sheep, and then dried at $65^{\circ} \mathrm{C}$ for 72 hours in a forced-air oven for partial dry matter (DM) determination. Dried, pooled feed and fecal samples were ground through a $1 \mathrm{~mm}$ screen in a Wiley mill (Ogawa Seiki Co., Ltd., Tokyo, Japan).

\section{Ruminal fluid and blood samples collection}

After the digestion and metabolism experiment, ruminal fluid and blood samples were collected 3 hours after feeding. Approximately $50 \mathrm{~mL}$ of ruminal fluid was taken from three regions of the rumen through the mouth of each sheep using a flexible pipe and syringe, strained through four layers of cheesecloth, and preserved in individual plastic tubes (Jolazadeh et al., 2019). And then a $5 \mathrm{~mL}$ blood sample was collected from the jugular vein into a non-heparinized vacuum tube from each sheep.

\section{Nutrients analyses in feed, feces and urine samples}

The nutrients concentration of feed, feces, and urine samples were examined according to the following Association of Official Analytical Chemists methods (AOAC, 2002): analytical DM (method 930.15), ash (method 942.05), calcium (Ca, method 978.02), total phosphorus (TP, method 946.06); neutral detergent fiber (NDF) and acid detergent fiber (ADF) were analyzed according to the methods of Goering \& Soest (1970). The nitrogen concentration of feed, feces with $10 \%$ sulfuric acid, and urine samples were determined by the Kjeldahl method (AOAC, 2002, method 990.03).

\section{Short-chain fatty acids analysis in ruminal fluid}

Short-chain fatty acids (SCFAs) were measured using an Agilent $6890 \mathrm{~N}$ gas chromatography system (Agilent Technologies, Inc., Santa Clara, CA, USA) with a $30 \mathrm{~m}(0.32 \mathrm{~mm}$ i.d.) fused silica column (HP-19091N-213I; Agilent) (Zheng et al., 2018). In brief, the ruminal fluid sample was centrifuged at $5,400 \mathrm{rpm}$ for $10 \mathrm{~min}$, and then $1 \mathrm{~mL}$ supernatant was transferred into a 1.5 $\mathrm{mL}$ centrifugal tube. Then $200 \mu \mathrm{L} 25 \%$ metaphosphoric acid solution contained $2 \mathrm{~g} / \mathrm{L} 2-$ ethylbutyric acid was added into tube and the tube was put into ice-water for more than $30 \mathrm{~min}$. After that, the tube was centrifuged at 10,000 rpm for $10 \mathrm{~min}$, and the supernatant was analyzed by gas chromatography. The gas chromatography condition was as follow: injection port temperature $220^{\circ} \mathrm{C}$; sample size $0.6 \mu \mathrm{L}$; carrier gas nitrogen; nitrogen flow rate $2 \mathrm{~mL} / \mathrm{min}$; split ratio $40: 1$; oven temperature $120^{\circ} \mathrm{C}$ for $3 \mathrm{~min}$, then $10^{\circ} \mathrm{C} / \mathrm{min}$ rising until $180^{\circ} \mathrm{C}$, maintaining for $1 \mathrm{~min}$; flame ionization detector temperature $250^{\circ} \mathrm{C}$, hydrogen flow rate $40 \mathrm{~mL} / \mathrm{min}$, air flow rate $450 \mathrm{~mL} / \mathrm{min}$, make-up gas flow rate $45 \mathrm{~mL} / \mathrm{min}$.

\section{Ammonia nitrogen concentration analysis in ruminal fluid}

The ammonia nitrogen concentration was measured using a spectrophotometer (SP-723;

Spectrum Instruments, Ltd., Shanghai, P. R. China) according to the Berthelot reaction (phenol-

Peer) reviewing PDF | (2021:01:56977:3:0:NEW 21 May 2021) 
202 hypochlorite) described by Broderick and Kang (1980). In brief, the ruminal fluid sample was 203 centrifuged at 4,000 rpm for $10 \mathrm{~min}$, and then $2 \mathrm{~mL}$ supernatant was transferred into a $15 \mathrm{~mL}$ 204 tube. Then $8 \mathrm{~mL} 0.2 \mathrm{~mol} / \mathrm{L}$ hydrochloric acid solution was added into the tube. $0.4 \mathrm{~mL}$ solution 205 was transferred into a tube and $2 \mathrm{~mL}$ solution A ( $0.08 \mathrm{~g}$ sodium nitroferricyanide dihydrate 206 dissolved in $14 \%$ sodium salicylate solution) and $2 \mathrm{~mL}$ solution B ( $2 \mathrm{~mL}$ sodium hypochlorite 207 dissolved in $100 \mathrm{~mL} 0.3 \mathrm{~mol} / \mathrm{L}$ sodium hydroxide solution) were added. The solution was shaken 208 up, and placed in tube shelf for reaction for $10 \mathrm{~min}$. After that, the ammonia concentration was 209 measured by colorimetry at $700 \mathrm{~nm}$ wave length to obtain optical density. While optical density 210 from different concentration ammonia standard solution also needed measurement to calculate 211 the ammonia concentration in ruminal fluid.

\section{Hematological parameters analysis in blood}

213 After blood samples collection, parameters including white blood cell (WBC) and red blood cell

214 (RBC) counts, hemoglobin (HGB) concentration, hematocrit (HCT), mean corpuscular volume 215 (MCV), mean corpuscular hemoglobin $(\mathrm{MCH})$, mean corpuscular hemoglobin concentration 216 (MCHC), red blood cell distribution width (RDW), platelet count (PLT), mean platelet volume 217 (MPV), platelet distribution width (PDW), and plateletcrit (PCT) were measured immediately 218 using a fully automatic hematology analyzer (Mindray BC-2800Vet, Shenzhen Mindray Bio219 Medical Electronics Co. Ltd., Shenzhen, Guangdong, P. R. China).

220 Statistical analysis

221 Because the single-factor experimental design was used in this experiment, the data were 222 analyzed by one-way ANOVA (SPSS 19.0; IBM Co., Chicago, IL, USA) using the following 223 model:

224

225

226

227

228

229

230

231

232

233

234

235

236

237

238

239

240

$$
X_{i j}=\mu+\alpha_{i}+e_{i j}
$$

where $X_{i j}$ is the observation of the dependent variable ( $i=1$ to $4, j=1$ to 6 ), $\mu$ is the population mean, $\alpha_{i}$ is the $i^{\text {th }}$ treatment effect, and $e_{i j}$ is the random error associated with the observation.

Significance was declared at $P \leq 0.05$ and tendency at $0.05<P \leq 0.10$ using Tukey's multiple comparison test.

\section{Results}

\section{Effects of different doses MOS on sheep growth performance}

There were no differences in final body weight, average daily weight gain, or average daily feed intake between treatment groups $(P>0.05$, Table 2$)$.

Please placed Table 2 here.

\section{Effects of different doses MOS on nutrient apparent digestibility and retention rate}

The DM and OM apparent digestibility of sheep fed the 1.6\% MOS diet were higher than those in sheep fed the $0 \% \operatorname{MOS} \operatorname{diet}(P=0.010, P=0.016$, Table 3$)$, and their NDF and ADF apparent digestibility were higher than those in the other treatment groups $(P=0.003, P=0.028, P=$ $0.001 ; P=0.001, P=0.029, P<0.001)$. In addition, the $\mathrm{CP}$ apparent digestibility of sheep fed the $1.6 \%$ MOS diet was higher than those in sheep fed the $0 \%$ and $0.8 \% \operatorname{MOS} \operatorname{diet}(P=0.040, P$ 
$241=0.044$, Table 4$)$. There were no differences in the apparent digestibility of other nutrients or in

242 the retention rates of sheep between treatment groups $(P>0.05)$.

243 Please placed Table 3 and 4 here.

244 Effects of different doses MOS on ruminal fluid and hematological parameters

245 Supplementation dietary MOS did not affect SCFAs concentration, ratios of individual fatty

246 acids to total SCFAs, or C2/C3 ratios $(P>0.05)$; however, the ammonia concentration $\left(\mathrm{NH}_{3}-\mathrm{N}\right)$

247 of ruminal fluid from sheep fed the $1.6 \%$ and $2.4 \%$ MOS diets were lower than that of sheep fed

248 the $0 \% \operatorname{MOS} \operatorname{diet}(P=0.035, P=0.013$, Table 5).

$249 \quad$ Please placed Table 5 here.

250 Similarly, supplementation dietary MOS did not affect the hematological parameters of sheep

$251(P>0.05)$, and there was only a tendency regarding MOS increasing the MCHC concentration in $252 \operatorname{blood}(P=0.068$, Table 6$)$.

$253 \quad$ Please placed Table 6 here.

254 Discussion

255 Effects of different doses MOS on sheep growth performance

256 Many studies have concluded that supplementation dietary MOS improve the performance of 257 monogastric animals. Supplementation dietary MOS improved growth performance and gut 258 health in broiler chickens (Soumeh et al., 2019), and increased feed utilization and amino acid 259 digestibility in White Pekin ducks (Park, Jung \& Carey, 2019), as well as improved growth 260 performance and modulation of intestinal microbial populations in Japanese quail (Hazrati, 261 Rezaeipour \& Asadzadeh, 2019). Supplementation dietary MOS maintained the normal intestinal 262 health of rats (Yazbeck et al., 2019), and effectively replaced antibiotics as growth promoters in 263 raising guinea pigs (Minguez, Ingresa-Capaccioni \& Calvo, 2019). Additionally,

264 supplementation dietary MOS improved the growth performance, antioxidant capacity and 265 immunity of aquatic animals (Lu et al., 2019; Meng et al., 2019; Mohammadian et al., 2019; 266 Widanarni et al., 2019). However, the studies focused on MOS in ruminants have drawn 267 inconsistent conclusions. Westland et al. (2017) reported that supplementation dietary MOS 268 increased the colostrum yield of dairy cows, but had no effect on calf health and weight gain. da 269 Silva, Bittar \& Ferreira (2012) observed that supplementation dietary MOS did not improve calf 270 performance when added to a milk replacer or starter concentrate. Morrison, Dawson \& Carson 271 (2010) reported no effects on calf performance, even though supplementation with MOS 272 increased concentrate intake in the early lives of calves. Similarly, supplementation dietary MOS 273 have been shown not to influence body weight gain in lambs (Demirel et al., 2007). Consistently 274 with some of these previous studies, supplementation dietary MOS did not impact average feed 275 intake or average daily weight gain of sheep in the current study (refer to Table 2). This may be 276 because ruminal microbes degrade MOS in the rumen (Dai et al., 2015; Wang et al., 2019), and 277 then supplementation dietary MOS could regulate the composition of ruminal microbiota and 278 chyme, even changed ruminal fermentation type and nutrients transfer in small intestine (Diaz et 279 al., 2018) but the efficiency was not enough to change growth performance. This indicates that 
280

281

282

283

284

285

286

287

288

289

290

291

292

293

294

295

296

297

298

299

300

301

302

303

304

305

306

307

308

309

310

311

312

313

314

315

316

317

318

319

MOS are suitable for nutritional regulation purposes in adult ruminants, but not for growth performance enhancement in sheep.

\section{Effects of different doses MOS on nutrient apparent digestibility and retention rate} In this study, the DM, OM, NDF, ADF, CP, and ash apparent digestibility of sheep were significantly increased through supplementation with MOS, especially at a dose of $1.6 \%$ (refer to Table 3 and 4). MOS are a type of carbohydrate that can be degraded by ruminal microbes (Dai et al., 2015; Wang et al., 2019). Indeed, supplementation dietary MOS has potential to maintain stable ruminal environment by regulating ruminal microbiota, then the composition of chyme from rumen and to duodenum changed, consequently, some oligosaccharides went to small intestine because of MOS not degraded 100\% in rumen and nutrients digestion and absorption in small intestine regulated by MOS (Diaz et al., 2018). Because supplementation dietary MOS brought long villi and shallow crypts which provided a larger surface area for nutrients absorption in small intestine of animals (Chacher et al., 2017), and an our previous study also demonstrated that supplementation dietary MOS elongated the villus height and the muscular thickness, and decreased the villus width of lamb duodenum significantly (Zheng et al., 2020), so, the monitoring results about supplementation dietary MOS improved nutrient digestion of sheep in the current study were observed. And some previous studies have reported similar results, with MOS increasing the digestion of NDF and ADF (Zheng et al., 2018), and nitrogen retention in sheep (Zheng et al., 2018; Zheng et al., 2019), as well as improving the nitrogen, zinc, and iron metabolism of calves and lambs (Cole, Purdy \& Hutcheson, 1992). However, another study reported that MOS did not affect nutrient digestibility in dairy cows (Moallem et al., 2009). Thus, future research confirming the effects of MOS on nutrient utilization by ruminants is warranted.

\section{Effects of different doses MOS on ruminal fluid and hematological parameters}

In the current study, MOS did not change the SCFAs concentration or ratios of individual fatty acids to total SCFAs; however, it significantly decreased the ruminal ammonia concentration (refer to Table 5). In the rumen, lower ammonia level indicates active microbial proliferation, and microbial protein synthesis and nitrogen metabolism are improved (Diaz et al., 2018). As a result, nitrogen utilization by the sheep improved, which is consistent with our observations of nutrient utilization. Previous reports have indicated that supplementation dietary MOS improve the ruminal microbial composition and ammonia levels: the supplementation of a high-grain diet with MOS decreased ruminal ammonia concentration in sheep (Diaz et al., 2018) and slightly reduced ruminal ammonia concentration in sheep rumens 1-5 hours after feeding (Zheng et al., 2018); live yeast supplementation also reduced ruminal ammonia concentration in dairy cows (Moallem et al., 2009). Other oligosaccharides have shown similar properties: the addition of chitosan to a 50:50 concentrate:forage diet decreased ruminal ammonia concentration in sheep (Goiri, Oregui \& Garcia-Rodriguez, 2010), and the supplementation with $\beta$ 1-4 galactooligosaccharides also reduced ruminal ammonia concentration in sheep (Mwenya et al., 2004). In addition, although ruminal SCFAs concentration was not influenced by MOS significantly, but supplementation dietary MOS decreased SCFAs concentration. This may be supplementation 
320

321

322

323

324

325

326

327

328

329

330

331

332

333

334

335

336

337

338

339

340

341

342

343

344

345

346

347

348

349

350

351

352

353

354

355

356

357

358

359

dietary MOS could increase SCFAs concentration (Diaz et al., 2018), and then more SCFAs could stimulate the expression of transport proteins like monocarboxylate transporter 1 (MCT1) and $\mathrm{Na}^{+} / \mathrm{H}^{+}$exchangers (NHEs) and free fatty acid receptors (FFARs), consequently, more SCFAs were absorbed by ruminal epithelium (Baaske et al., 2020). As a result, the decrease of SCFAs concentration in sheep rumen was monitored in the current study because the ruminal fluid was sampled 3 hours after feeding. These results illuminate the potential of MOS to improve ruminal fermentation and nitrogen utilization in ruminants, but the further research is guaranteed to confirm the actual effects of MOS regulating rumen fermentation.

Hematological parameters are typically auxiliary indexes used to monitor health conditions or metabolic processes of animals. When used as an animal feed additive, supplementation dietary MOS improves digestion, the immune system, and the microbiota of the gastrointestinal tract. However, because their effects on the animal body are slight, basal hematological parameters are not greatly influenced by MOS. In the present study, supplementation dietary MOS did not influence the hematological parameters of sheep (refer to Table 6). Similarly, supplementation dietary MOS did not affect the WBC count, HCT, neutrophil count, mononuclear leukocyte count, or eosinophil count of dairy cows or their offspring (Franklin et al., 2005). Other studies on the effects of MOS in monogastric animals have reported similar results: supplementation dietary MOS did not impact RBC count, hemoglobin, HCT, or MCHC of weanling pigs in one study (Valpotić et al., 2017; dos Anjos et al., 2019), or RBC count, WBC count, lymphocyte count, or diarrhea score in another study (Zhao, Jung \& Kim, 2012), and did not influence monocyte, basophil, or eosinophil counts in Arbor Acres broiler chickens (Attia et al., 2017).

\section{Conclusions}

In the current study, the efficiency of supplementation dietary MOS on growth performance, nutrients apparent digestibility, rumen fermentation, and some hematological parameters were assessed in $H u$ sheep under actual breeding conditions. Although supplementation dietary MOS did not affect growth performance, ruminal SCFAs concentration and ratios of individual fatty acids to total SCFAs, C2/C3 ratios, or hematological parameters in sheep, these oligosaccharides increased DM, OM, CP, NDF, ADF, and ash apparent digestibility and decreased the ruminal ammonia concentration significantly. This indicates that supplementation dietary MOS improve nutrient utilization, especially nitrogen metabolism, in ruminants. In the future, the ruminal microbiota, ruminal microorganism metabolism, and relationship between gastrointestinal microorganism and host regulating by MOS should be investigated, and eventually reveal the molecule mechanism.

\section{Acknowledgements}

This study was supported by the National Natural Science Foundation of China (No. 31860657). We thank everyone who participated in this experiment. We would also like to thank Editage (www.editage.cn) for English language editing.

\section{Funding information}

National Natural Science Foundation of China, grant number: 31860657.

\section{Conflict of interest}


360

361

362

363

364

365

366

367

368

369

370

371

372

373

374

375

376

377

378

379

380

381

382

383

384

385

386

387

388

389

390

391

392

393

394

395

396

397

398

399

400

Authors declare no conflict of interests for this article.

\section{Author Contributions}

Chen Zheng and Ting Liu conceived and designed the experiments, performed the experiments, analyzed the data, prepared tables, authored or reviewed drafts of the paper, and approved the final draft.

Juwang Zhou and Yanqin Zeng performed the experiments, analyzed the data, prepared tables, authored or reviewed drafts of the paper, and approved the final draft.

\section{References}

Abd El-Hack, ME, El-Saadony MT, Shafi ME, Alshahrani OA, Saghir SAM, Al-wajeeh AS, Al-shargi OYA, Taha AE, Mesalam NM, Abdel-Moneim AME. 2021. Prebiotics can restrict Salmonella populations in poultry: a review. Animal Biotechnology DOI: 10.1080/10495398.2021.1883637.

Association of Official Analytical Chemists (AOAC). 2002. Official methods of analysis of AOAC international (17th ed.). Gaithersburg, MD: AOAC International.

Attia YA, Al-Khalaifah H, Ibrahim MS, Abd Al-Hamid AE, Al-Harthi MA, El-Naggar A. 2017. Blood hematological and biochemical constituents, antioxidant enzymes, immunity and lymphoid organs of broiler chicks supplemented with propolis, bee pollen and mannan oligosaccharides continuously or intermittently. Poultry Science 96(12): 41824192 DOI: $10.3382 / \mathrm{ps} / \mathrm{pex} 173$.

Baaske L, Masur F, Dengler F, Rackwitz R, Kaiser B, Pfannkuche H, Gabel G. 2020. Possible influence of free fatty acid receptors on $\mathrm{pH}$ regulation in the ruminal epithelium of sheep. Journal of Animal Physiololgy and Animal Nutrition 104(3):776-789 DOI: 10.1111/jpn.13308.

Broderick GA, Kang JH. 1980. Automated simultaneous determination of ammonia and total amino acids in ruminal fluid and in vitro media. Journal of Dairy Science 63(1): 64-75 DOI: $10.3168 / j$ ds.S0022-0302(80)82888-8.

Chacher MFA, Kamran Z, Ahsan U, Ahmad S, Koutoulis KC, Din HGQU, Cengiz Ö. 2017. Use of mannan oligosaccharide in broiler diets: an overview of underlying mechanisms. World's Poultry Science Journal 73(4):831-844 DOI: 10.1017/S0043933917000757.

Cole NA, Purdy CW, Hutcheson DP. 1992. Influence of yeast culture on feeder calves and lambs. Journal of Animal Science 70: 1682-1690 DOI: 10.2527/1992.7061682x.

Costa EIDS, Ribiero CVDM, Silva TM, Ribeiro RDX, Vieira JF, Lima AGVDO, Barbosa AM, Júnior JMDS, Bezerra LR, Oliveira RL. 2021. Intake, nutrient digestibility, nitrogen balance, serum metabolites and growth performance of lambs supplemented with Acacia mearnsii condensed tannin extract. Animal Feed Science and Technology 272:114744 DOI: 10.1016/j.anifeedsci.2020.114744.

da Silva JT, Bittar CMM, Ferreira LS. 2012. Evaluation of mannan-oligosaccharides offered in milk replacers or calf starters and their effect on performance and rumen development of dairy calves. Revista Brasileira de Zootecnia 41(3): 746-752 DOI: 10.1590/S151635982012000300038 .

Dai X, Tian Y, Li JT, Su XY, Wang XW, Zhao SG, Liu L, Luo YF, Liu D, Zheng HJ, Wang

Peer) reviewing PDF | (2021:01:56977:3:0:NEW 21 May 2021) 
401

402

403

404

405

406

407

408

409

410

411

412

413

414

415

416

417

418

419

420

421

422

423

424

425

426

427

428

429

430

431

432

433

434

435

436

437

438

439

440

JQ, Dong ZY, Hu SN, Huang L. 2015. Metatranscriptomic analyses of plant cell wall polysaccharide degradation by microorganisms in the cow rumen. Applied and Environmental Microbiology 81(4):1375-1386 DOI: 10.1128/AEM.03682-14.

Demirel G, Turan N, Tanor A, Kocabagli N, Alp M, Hasoksuz M, Yilmaz H. 2007. Effects of dietary mannanoligosaccharide on performance, some blood parameters, IgG levels and antibody response of lambs to parenterally administered E. coli O157:H7. Archives of Animal Nutrition 61(2): 126-134 DOI: 10.1080/17450390701222964.

Diaz GT, Branco AF, Jacovaci FA, Jobim CC, Bolson DC, Daniel JLP. 2018. Inclusion of live yeast and mannan-oligosaccharides in high grain-based diets for sheep: Ruminal parameters, inflammatory response and rumen morphology. Plos One 13(2):e0193313 DOI: 10.1371/journal.pone.0193313.

dos Anjos CM, Gois FD, dos Anjos CM, Rocha VDS, Castro DEDS, Allaman IB, Silva FL, Carvalho PLDO, Meneghetti C, Costa LB. 2019. Effects of dietary beta-glucans, glucomannans and mannan oligosaccharides or chlorohydroxyquinoline on the performance, diarrhea, hematological parameters, organ weight and intestinal health of weanling pigs. Livestock Science 223: 39-46 DOI: 10.1016/j.livsci. 2019.02.018.

Franklin ST, Newman MC, Newman KE, Meek KI. 2005. Immune parameters of dry cows fed mannan oligosaccharide and subsequent transfer of immunity to calves. Journal of Dairy Science 88: 766-775 DOI: 10.3168/jds.S0022-0302(05)72740-5.

Goering HR, Soest PJV. 1970. Forage Fiber Analysis. Agricultural Handbook No. 379. Department of Agriculture, Washington, DC, US.

Goiri I, Oregui LM, Garcia-Rodriguez A. 2010. Use of chitosans to modulate ruminal fermentation of a 50:50 forage-to-concentrate diet in sheep. Journal of Animal Science 88: 749-755 DOI: 10.2527/jas.2009-2377.

Hazrati S, Rezaeipour V, Asadzadeh S. 2019. Effects of phytogenic feed additives, probiotic and mannan-oligosaccharides on performance, blood metabolites, meat quality, intestinal morphology, and microbial population of Japanese quail. British Poultry Science 11: 1-8 DOI: $10.1080 / 00071668.2019 .1686122$.

Jolazadeh AR, Mohammadabadi T, Dehghan-banadaky M, Chaji M, Garcia M. 2019. Effect of supplementation fat during the last 3 weeks of uterine life and the preweaning period on performance, ruminal fermentation, blood metabolites, passive immunity and health of the newborn calf. British Journal of Nutrition 122(12):1346-1358 DOI: 10.1017/S0007114519002174.

Linneen SK, Mourer GL, Sparks JD, Jennings JS, Goad CL, Lalman DL. 2014. Effects of mannan oligosaccharide on beef-cow performance and passive immunity transfer to calves. The Professional Animal Scientist 30: 311-317 DOI: 10.15232/S10807446(15)30122-4.

Lu JT, Qi CL, Limbu SM, Han FL, Yang L, Wang XD, Qin JG, Chen LQ. 2019. Dietary mannan oligosaccharide (MOS) improves growth performance, antioxidant capacity, non-specific immunity and intestinal histology of juvenile Chinese mitten crabs 
441

442

443

444

445

446

447

448

449

450

451

452

453

454

455

456

457

458

459

460

461

462

463

464

465

466

467

468

469

470

471

472

473

474

475

476

477

478

479

480

(Eriocheir sinensis). Aquaculture 510: 337-346 DOI: 10.1016/j.aquaculture.2019.05.048. Meng XX, Yang XY, Lin G, Fang Y, Ruan ZL, Liu MF, Liu GX, Li MZ, Yang DL. 2019. Mannan oligosaccharide increases the growth performance, immunity and resistance capability against Vibro Parahemolyticus in juvenile abalone Haliotis discus hannai Ino. Fish and Shellfish Immunology 94: 654-660 DOI: 10.1016/j.fsi.2019.09.058.

Minguez C, Ingresa-Capaccioni S, Calvo A. 2019. Effects of mannan oligosaccharide dietary supplementation on mortality, growth performance and carcass traits in meat Guinea pigs. Journal of Applied Animal Research 47(1): 539-544 DOI: 10.1080/09712119.2019.1682590.

Moallem U, Lehrer H, Livshitz L, Zachut M, Yakoby S. 2009. The effects of live yeast supplementation to dairy cows during the hot season on production, feed efficiency, and digestibility. Journal of Dairy Science 92: 343-351 DOI: 10.3168/jds.2007-0839.

Mohammadian T, Nasirpour M, Tabandeh MR, Mesbah M. 2019. Synbiotic effects of $\beta$ glucan, mannan oligosaccharide and Lactobacillus casei on growth performance, intestine enzymes activities, immune-hematological parameters and immune-related gene expression in common carp, Cyprinus carpio: An experimental infection with Aeromonas hydrophila. Aquaculture 511: 634197 DOI:10.1016/j.aquaculture.2019.06.011.

Morrison SJ, Dawson S, Carson AF. 2010. The effects of mannan oligosaccharide and Streptococcus faecium addition to milk replacer on calf health and performance. Livestock Science 131(2-3): 292-296 DOI: 10.1016/ j.livsci.2010.04.002.

Mwenya B, Santoso B, Sar C, Gamo Y, Kobayashi T, Arai I, Takahashi J. 2004. Effects of including $\beta-1,4$ galacto-oligosaccharides, lactic acid bacteria or yeast culture on methanogenesis as well as energy and nitrogen metabolism in sheep. Animal Feed Science and Technology 115: 313-326 DOI: 10.1016/j.anifeedsci.2004.03.007.

Park J, Jung S, Carey JB. 2019. Effects of a commercial mannan-oligosaccharide product on growth performance, intestinal histomorphology, and amino acid digestibility in White Pekin Ducks. Journal of Applied Poultry Research 28(1): 72-77 DOI: 10.3382/japr/pfy017.

Ren ZL, Wang SF, Cai Y, Wu Y, Tian LJ, Wang SQ, Jiang L, Guo WL, Sun Y, Zhou YC. 2020. Effects of dietary mannan oligosaccharide supplementation on growth performance, antioxidant capacity, non-specific immunity and immune-related gene expression of juvenile hybrid grouper (Epinephelus lanceolatus $\widehat{\bigcirc} \times$ Epinephelus fuscoguttatus +). Aquaculture 523:735195 DOI: 10.1016/j.aquaculture.2020.735195.

Sinz S, Leparmarai PT, Liesegang A, Ortmann S, Kreuzer M, Marquardt S. 2021. Effects of dietary grapeseed extract on performance, energy and nitrogen balance as well as methane and nitrogen losses of lambs and goat kids. British Journal of Nutrition 125(1):26-37 DOI: 10.1017/S0007114520002512.

Soumeh EA, Mohebodini H, Toghyani M, Shabani A, Ashayerizadeh A, Jazi, V. 2019. Synergistic effects of fermented soybean meal and mannan-oligosaccharide on growth performance, digestive functions, and hepatic gene expression in broiler chickens. 
481

482

483

484

485

486

487

488

489

490

491

492

493

494

495

496

497

498

499

500

501

502

503

504

505

506

507

508

509

510

511

512

513

514

515

516

517

518

519

520

Poultry Science 98(12): 6797-6807 DOI: 10.3382/ps/pez409.

Valpotić H, Barić-Rafaj R, Mrljak V, Grabarević Ž, Samardžija M, Šperanda M, Žaja IŽ, Đuričić D, Bach A, Harapin I, Folnožić I, Vince S, Valpotić I. 2017. Influence of dietary mannan oligosaccharide and clinoptilolite on hematological, biochemical and gut histological parameters in weaned pigs. Periodicum Biologorum 119(1): 63-73 DOI: 10.18054/ pb.v119i1.4407.

Van den Abbeele P, C. Duysburgh M, Rakebrandt M, Marzorati M. 2020. Dried yeast cell walls high in beta-glucan and mannan-oligosaccharides positively affect microbial composition and activity in the canine gastrointestinal tract in vitro. Journal of Animal Science 98(6): 1-10 DOI: 10.1093/jas/skaa173.

Wang LJ, Zhang GN, Xu HJ, Xin HS, Zhang YG. 2019. Metagenomic analyses of microbial and carbohydrate-active enzymes in the rumen of Holstein cows fed different forage-toconcentrate ratios. Frontiers in Microbiologh 10:649 DOI: 10.3389/fmicb.2019.00649.

Westland A, Martin R, White R, Martin JH. 2017. Mannan oligosaccharide prepartum supplementation: effects on dairy cow colostrum quality and quantity. Animal 11(10): 1779-1782 DOI: 10.1017/S1751731117000672.

Widanarni W, Taufik A, Yuhana M, Ekasari J. 2019. Dietary mannan oligosaccharides positively affect the growth, digestive enzyme activity, immunity and resistance against Vibrio harveyi of Pacific White Shrimp (Litopenaeus vannamei) Larvae. Turkish Journal of Fisheries and Aquatic Sciences 19(4): 271-278 DOI: 10.4194/1303-2712-v19_4_01.

Yazbeck R, Lindsay RJ, Geier MS, Butler RN, Howarth GS. 2019. Prebiotics fructo-, galacto-, and mannan-oligosaccharide do not protect against 5-fluorouracil-induced intestinal mucositis in rats. Journal of Nutrition 149(12): 2164-2173 DOI: 10.1093/jn/nxz192.

Zhao PY, Jung JH, Kim IH. 2012. Effect of mannan oligosaccharides and fructan on growth performance, nutrient digestibility, blood profile, and diarrhea score in weanling pigs. Journal of Animal Science 90(3): 833-839 DOI:10.2527/jas.2011-3921.

Zheng C, Li FD, Hao ZL, Liu T. 2018. Effects of adding mannan oligosaccharides on digestibility and metabolism of nutrients, ruminal fermentation parameters, immunity, and antioxidant capacity of sheep. Journal of Animal Science 96(1): 284-292 DOI: 10.1093/jas/skx040.

Zheng C, Li FD, Li F, Zhou JW, Duan PW, Liu HH, Fan HM, Zhu WL, Liu T. 2020. Effects of adding mannan oligosaccharides to milk replacer on the development of gastrointestinal tract of 7-28 days old Hu lambs. Scientia Agricultura Sinica 53(2):398408 DOI: 10.3864/j.issn.0578-1752.2020.02.014.

Zheng C, Ma JJ, Liu T, Wei BD, Yang HM. 2019. Effects of mannan oligosaccharides on gas emission, protein and energy utilization, and fasting metabolism in sheep. Animals 9: 741 DOI: $10.3390 /$ ani9100741.

Zhou H, Yu B, He J, Mao XB, Zheng P, Yu J, Luo JQ, Luo YH, Yan H, Chen DW. 2020. The optimal combination of dietary starch, non-starch polysaccharides, and mannan- 
$521 \quad$ oligosaccharide increases the growth performance and improves butyrate-producing 522 bacteria of weaned pigs. Animals 10(10):1745 DOI: 10.3390/ani10101745.

523

524 


\section{Table $\mathbf{1}$ (on next page)}

Ingredients and chemical composition of experimental diets.

${ }^{1}$ Mineral and vitamin mix was formulated with $200 \mathrm{mg} / \mathrm{kg}$ of S, $25.0 \mathrm{mg} / \mathrm{kg}$ of Fe, $40.0 \mathrm{mg} / \mathrm{kg}$ of Zn, $8 \mathrm{mg} / \mathrm{kg}$ of Cu, $0.3 \mathrm{mg} / \mathrm{kg}$ of I, $40.0 \mathrm{mg} / \mathrm{kg}$ of Mn, $0.2 \mathrm{mg} / \mathrm{kg}$ of Se, $0.1 \mathrm{mg} / \mathrm{kg}$ of Co, 940

$\mathrm{IU} / \mathrm{kg}$ of vitamin $\mathrm{A}$, and $20 \mathrm{IU} / \mathrm{kg}$ of vitamin $\mathrm{E} .{ }^{2} \mathrm{MOS}=$ mannan oligosaccharides 
1 Table 1:

2 Ingredients and chemical composition of experimental diets.

\begin{tabular}{|c|c|c|c|c|}
\hline \multirow[b]{2}{*}{ Items } & \multicolumn{4}{|l|}{ MOS $^{2}$} \\
\hline & $0 \%$ & $0.8 \%$ & $1.6 \%$ & $2.4 \%$ \\
\hline \multicolumn{5}{|l|}{ Ingredients, $\mathrm{g} / \mathrm{kg}$} \\
\hline Maize & 400.0 & 400.0 & 427.4 & 456.5 \\
\hline Soybean meal & 120.0 & 130.0 & 135.0 & 150.0 \\
\hline Sunflower skin & 90.0 & 90.0 & 89.0 & 90.0 \\
\hline Malt sprout & 122.2 & 104.2 & 108.8 & 85.7 \\
\hline Barley & 63.0 & 67.0 & 30.0 & 30.0 \\
\hline Cottonseed meal & 5.0 & 5.0 & 2.0 & 3.0 \\
\hline Maize straw & 160.0 & 156.0 & 152.0 & 148.0 \\
\hline Salt & 6.8 & 6.8 & 6.8 & 6.8 \\
\hline Puffing urea & 13.0 & 13.0 & 13.0 & 13.0 \\
\hline Sodium bicarbonate & 15.0 & 15.0 & 15.0 & 15.0 \\
\hline Mineral and vitamin $\operatorname{mix}^{1}$ & 5.0 & 5.0 & 5.0 & 5.0 \\
\hline Mannan oligosaccharides (MOS) & - & 8.0 & 16.0 & 24.0 \\
\hline \multicolumn{5}{|l|}{ Chemical composition, g/kg DM } \\
\hline Crude protein & 182.6 & 182.4 & 181.8 & 181.8 \\
\hline Calcium & 3.9 & 3.8 & 3.8 & 3.6 \\
\hline Phosphorus & 3.2 & 3.1 & 3.1 & 3.0 \\
\hline Neutral detergent fiber (NDF) & 317.3 & 309.0 & 299.5 & 285.2 \\
\hline Acid detergent fiber (ADF) & 193.6 & 189.9 & 185.6 & 181.0 \\
\hline Starch & 333.7 & 333.8 & 331.5 & 333.4 \\
\hline Ether extract & 21.3 & 20.9 & 21.0 & 20.6 \\
\hline Ash & 32.1 & 32.9 & 31.2 & 30.8 \\
\hline Metabolic energy, MJ/kg DM & 10.4 & 10.4 & 10.3 & 10.3 \\
\hline
\end{tabular}

$3{ }^{1}$ Mineral and vitamin mix was formulated with $200 \mathrm{mg} / \mathrm{kg}$ of S, $25.0 \mathrm{mg} / \mathrm{kg}$ of Fe, $40.0 \mathrm{mg} / \mathrm{kg} \mathrm{of} \mathrm{Zn,} 8 \mathrm{mg} / \mathrm{kg} \mathrm{of} \mathrm{Cu}$,

$40.3 \mathrm{mg} / \mathrm{kg}$ of I, $40.0 \mathrm{mg} / \mathrm{kg}$ of Mn, $0.2 \mathrm{mg} / \mathrm{kg}$ of Se, $0.1 \mathrm{mg} / \mathrm{kg}$ of Co, $940 \mathrm{IU} / \mathrm{kg}$ of vitamin A, and $20 \mathrm{IU} / \mathrm{kg}$ of vitamin 5 E.

$6 \quad 2 \mathrm{MOS}=$ mannan oligosaccharides 


\section{Table 2 (on next page)}

Effects of different doses of MOS on growth performance in sheep.

${ }^{1}$ Sheep were fed $0,0.8,1.6$, or $2.4 \% \operatorname{MOS}$ ( $n=24$ per treatment). The mean growth performance results for the 96 sheep according to MOS level are shown for the 5-week collection phase of the study. ${ }^{2}$ MOS $=$ mannan oligosaccharides ${ }^{3} \mathrm{SEM}=$ standard error of the mean 
1 Table 2:

2 Effects of different doses of MOS on growth performance in sheep.

\begin{tabular}{|c|c|c|c|c|c|c|}
\hline \multirow{2}{*}{ Items $^{1}$} & \multicolumn{4}{|l|}{ MOS $^{2}$} & \multirow{2}{*}{$\operatorname{SEM}^{3}$} & \multirow{2}{*}{$P$-value } \\
\hline & $0 \%$ & $0.8 \%$ & $1.6 \%$ & $2.4 \%$ & & \\
\hline Initial weight, kg & 30.82 & 31.14 & 31.25 & 31.25 & 0.276 & 0.940 \\
\hline Average daily intake, $\mathrm{g} / \mathrm{d}$ & 1595 & 1540 & 1556 & 1481 & 27.56 & 0.551 \\
\hline Final weight, $\mathrm{kg}$ & 38.37 & 37.74 & 38.77 & 38.58 & 0.374 & 0.782 \\
\hline Average daily gain, g/d & 207.1 & 190.9 & 213.5 & 214.6 & 7.578 & 0.667 \\
\hline
\end{tabular}

$3{ }^{1}$ Sheep were fed $0,0.8,1.6$, or $2.4 \% \operatorname{MOS}(n=24$ per treatment). The mean growth performance results for the 96

4 sheep according to MOS level are shown for the 5-week collection phase of the study.

$5 \quad{ }^{2} \mathrm{MOS}=$ mannan oligosaccharides

$6 \quad{ }^{3} \mathrm{SEM}=$ standard error of the mean 


\section{Table 3 (on next page)}

Effects of different doses of MOS on apparent digestibility of DM, OM, Ash, NDF and ADF in sheep.

${ }^{1}$ Sheep were fed $0,0.8,1.6$, or $2.4 \% \operatorname{MOS}$ ( $n=6$ per treatment). The mean digestion results are shown for each treatment over the 6-day collection phase of the study. ${ }^{2}$ MOS $=$ mannan oligosaccharides ${ }^{3} \mathrm{SEM}=$ standard error of the mean ${ }^{4} \mathrm{DM}=\operatorname{dry}$ matter ${ }^{5} \mathrm{OM}=$ organic matter ${ }^{6} \mathrm{NDF}=$ neutral detergent fiber ${ }^{7} \mathrm{ADF}=$ acid detergent fiber ${ }^{\mathrm{a}, \mathrm{b}}$ Means within rows with different superscript letters significantly differ $(P<0.05)$. 
1 Table 3:

2 Effects of different doses of MOS on apparent digestibility of DM, OM, Ash, NDF and ADF

3 in sheep.

\begin{tabular}{|c|c|c|c|c|c|c|}
\hline \multirow{2}{*}{ Items $^{1}$} & \multicolumn{4}{|l|}{ MOS $^{2}$} & \multirow{2}{*}{$\mathrm{SEM}^{3}$} & \multirow{2}{*}{$P$-value } \\
\hline & $\mathbf{0 \%}$ & $\mathbf{0 . 8 \%}$ & $1.6 \%$ & $2.4 \%$ & & \\
\hline \multicolumn{7}{|l|}{$\mathrm{DM}^{4}$} \\
\hline Intake, $\mathrm{g} / \mathrm{d}$ & 1118 & 1226 & 1103 & 1271 & 58.72 & 0.717 \\
\hline $\mathrm{DM}$ in feces, $\mathrm{g} / \mathrm{d}$ & 367.9 & 375.8 & 313.1 & 382.7 & 17.52 & 0.508 \\
\hline Digested DM, g/d & 750.0 & 849.7 & 789.7 & 888.6 & 42.76 & 0.696 \\
\hline Apparent digestibility, $\%$ & $66.66^{\mathrm{b}}$ & $68.93^{\mathrm{ab}}$ & $72.01^{\mathrm{a}}$ & $69.76^{\mathrm{ab}}$ & 0.636 & 0.017 \\
\hline \multicolumn{7}{|l|}{$\mathrm{OM}^{5}$} \\
\hline Intake, $\mathrm{g} / \mathrm{d}$ & 1021 & 1120 & 1014 & 1174 & 53.99 & 0.693 \\
\hline OM in feces, $\mathrm{g} / \mathrm{d}$ & 303.9 & 316.4 & 262.4 & 315.5 & 15.08 & 0.573 \\
\hline Digested OM, g/d & 716.9 & 804.1 & 751.4 & 858.6 & 40.27 & 0.648 \\
\hline Apparent digestibility, \% & $69.91^{\mathrm{b}}$ & $71.40^{\mathrm{ab}}$ & $74.70^{\mathrm{a}}$ & $73.01^{\mathrm{ab}}$ & 0.601 & 0.020 \\
\hline \multicolumn{7}{|l|}{ Ash } \\
\hline Intake, $\mathrm{g} / \mathrm{d}$ & 97.14 & 105.0 & 89.09 & 97.20 & 4.854 & 0.744 \\
\hline Ash in feces, $g / d$ & 63.95 & 59.41 & 50.76 & 67.19 & 2.637 & 0.134 \\
\hline Digested ash, g/d & 33.19 & 45.61 & 38.33 & 30.01 & 2.980 & 0.281 \\
\hline Apparent digestibility, \% & $32.54^{\mathrm{ab}}$ & $42.60^{\mathrm{a}}$ & $41.46^{\mathrm{ab}}$ & $30.45^{b}$ & 1.744 & 0.014 \\
\hline \multicolumn{7}{|l|}{$\mathrm{NDF}^{6}$} \\
\hline Intake, $\mathrm{g} / \mathrm{d}$ & 323.0 & 347.0 & 328.8 & 329.8 & 16.51 & 0.967 \\
\hline NDF in feces, $\mathrm{g} / \mathrm{d}$ & 189.0 & 192.3 & 161.5 & 200.2 & 9.756 & 0.554 \\
\hline Digested NDF, g/d & 134.0 & 154.7 & 167.2 & 129.5 & 8.611 & 0.386 \\
\hline Apparent digestibility, \% & $41.17^{\mathrm{b}}$ & $43.87^{\mathrm{b}}$ & $52.12^{\mathrm{a}}$ & $39.14^{\mathrm{b}}$ & 1.356 & 0.001 \\
\hline \multicolumn{7}{|l|}{$\mathrm{ADF}^{7}$} \\
\hline Intake, $\mathrm{g} / \mathrm{d}$ & 156.8 & 170.0 & 161.1 & 166.6 & 8.109 & 0.951 \\
\hline ADF in feces, $\mathrm{g} / \mathrm{d}$ & 110.7 & 110.6 & 93.71 & 118.7 & 5.648 & 0.484 \\
\hline Digested ADF, g/d & 46.13 & 59.35 & 67.37 & 47.96 & 3.718 & 0.138 \\
\hline Apparent digestibility, \% & $29.06^{\mathrm{b}}$ & $34.22^{\mathrm{b}}$ & $42.95^{\mathrm{a}}$ & $28.60^{\mathrm{b}}$ & 1.529 & $<0.001$ \\
\hline
\end{tabular}

$4{ }^{1}$ Sheep were fed $0,0.8,1.6$, or $2.4 \% \operatorname{MOS}(n=6$ per treatment). The mean digestion results are shown for each

5 treatment over the 6-day collection phase of the study.

$6 \quad{ }^{2} \mathrm{MOS}=$ mannan oligosaccharides

$7 \quad{ }^{3} \mathrm{SEM}=$ standard error of the mean

$8 \quad{ }^{4} \mathrm{DM}=$ dry matter

$9 \quad{ }^{5} \mathrm{OM}=$ organic matter 
$10 \quad{ }^{6} \mathrm{NDF}=$ neutral detergent fiber

$11{ }^{7} \mathrm{ADF}=$ acid detergent fiber

$12{ }^{\mathrm{a}, \mathrm{b}}$ Means within rows with different superscript letters significantly $\operatorname{differ}(P<0.05)$. 


\section{Table 4 (on next page)}

Effects of different doses of MOS on retention rate of $\mathrm{CP}$ and apparent digestibility of $\mathrm{CP}$, $\mathrm{Ca}$, and TP in sheep.

${ }^{1}$ Sheep were fed $0,0.8,1.6$, or $2.4 \% \operatorname{MOS}(n=6$ per treatment). The mean of digestion and retention results are shown for each treatment over the 6-day collection phase of the study. ${ }^{2}$ MOS $=$ mannan oligosaccharides ${ }^{3} \mathrm{SEM}=$ standard error of the mean ${ }^{4} \mathrm{CP}=$ crude protein ${ }^{5}$ $\mathrm{Ca}=$ calcium ${ }^{6} \mathrm{TP}=$ total phosphorus. ${ }^{\mathrm{a}, \mathrm{b}}$ Means within rows with different superscript letters significantly differ $(P<0.05)$. 
1 Table 4:

2 Effects of different doses of MOS on retention rate of $\mathrm{CP}$ and apparent digestibility of $\mathrm{CP}$,

3 Ca, and TP in sheep.

\begin{tabular}{|c|c|c|c|c|c|c|}
\hline \multirow{2}{*}{ Items $^{1}$} & \multicolumn{4}{|l|}{ MOS $^{2}$} & \multirow{2}{*}{ SEM $^{3}$} & \multirow{2}{*}{$P$-value } \\
\hline & $0 \%$ & $0.8 \%$ & $1.6 \%$ & $2.4 \%$ & & \\
\hline \multicolumn{7}{|l|}{$\mathrm{CP}^{4}$} \\
\hline Intake, $\mathrm{g} / \mathrm{d}$ & 200.5 & 221.3 & 224.9 & 227.0 & 9.105 & 0.738 \\
\hline $\mathrm{CP}$ in feces, $\mathrm{g} / \mathrm{d}$ & 63.34 & 69.74 & 63.19 & 64.16 & 2.483 & 0.777 \\
\hline $\mathrm{CP}$ in urine, $\mathrm{g} / \mathrm{d}$ & 79.68 & 73.26 & 87.11 & 90.76 & 4.525 & 0.545 \\
\hline Digested CP, g/d & 137.1 & 151.6 & 161.7 & 162.8 & 7.083 & 0.571 \\
\hline Apparent digestibility, \% & $67.90^{\mathrm{b}}$ & $68.00^{\mathrm{b}}$ & $72.16^{\mathrm{a}}$ & $71.61^{\mathrm{ab}}$ & 0.719 & 0.045 \\
\hline Retained CP, g/d & 57.45 & 78.33 & 74.61 & 72.06 & 6.134 & 0.662 \\
\hline Retention rate, $\%$ & 27.81 & 34.35 & 33.09 & 31.70 & 1.938 & 0.677 \\
\hline \multicolumn{7}{|l|}{$\mathrm{Ca}^{5}$} \\
\hline Intake, $\mathrm{g} / \mathrm{d}$ & 5.470 & 5.578 & 5.232 & 6.260 & 0.282 & 0.637 \\
\hline $\mathrm{Ca}$ in feces, $\mathrm{g} / \mathrm{d}$ & 5.342 & 5.365 & 4.811 & 5.818 & 0.214 & 0.451 \\
\hline Digested $\mathrm{Ca}, \mathrm{g} / \mathrm{d}$ & 0.127 & 0.213 & 0.422 & 0.442 & 0.133 & 0.816 \\
\hline Apparent digestibility, \% & -0.971 & 2.548 & 4.390 & 6.423 & 2.670 & 0.814 \\
\hline \multicolumn{7}{|l|}{$\mathrm{TP}^{6}$} \\
\hline Intake, $\mathrm{g} / \mathrm{d}$ & 4.430 & 4.566 & 4.057 & 4.933 & 0.225 & 0.613 \\
\hline $\mathrm{TP}$ in feces, $\mathrm{g} / \mathrm{d}$ & 3.600 & 3.371 & 3.186 & 3.544 & 0.133 & 0.716 \\
\hline Digested TP, g/d & 0.831 & 1.195 & 0.871 & 1.389 & 0.137 & 0.441 \\
\hline Apparent digestibility, \% & 17.00 & 24.46 & 15.79 & 27.71 & 3.006 & 0.454 \\
\hline
\end{tabular}

$4{ }^{1}$ Sheep were fed $0,0.8,1.6$, or $2.4 \% \operatorname{MOS}(n=6$ per treatment). The mean of digestion and retention results are shown

5 for each treatment over the 6-day collection phase of the study.

$62 \mathrm{MOS}=$ mannan oligosaccharides

$7 \quad{ }^{3} \mathrm{SEM}=$ standard error of the mean

$8 \quad{ }^{4} \mathrm{CP}=$ crude protein

$9 \quad{ }^{5} \mathrm{Ca}=$ calcium

$10 \quad{ }^{6} \mathrm{TP}=$ total phosphorus.

$11{ }^{\mathrm{a}, \mathrm{b}}$ Means within rows with different superscript letters significantly differ $(P<0.05)$. 


\section{Table 5 (on next page)}

Effects of different doses of MOS on ruminal fermentation parameters in sheep.

${ }^{1}$ Sheep were fed $0,0.8,1.6$, or $2.4 \% \operatorname{MOS}(n=6$ per treatment). The mean of ruminal fermentation parameters results are shown for each treatment after collection on the seventh day of the study. ${ }^{2}$ MOS $=$ mannan oligosaccharides ${ }^{3} \mathrm{SEM}=$ standard error of the mean ${ }^{4}$ SCFAs $=$ short-chain fatty acids ${ }^{5} \mathrm{C} 2 / \mathrm{C} 3=$ acetate/propionate ${ }^{\mathrm{a}, \mathrm{b}}$ Means within rows with different superscript letters significantly differ $(P<0.05)$. 
1 Table 5:

2 Effects of different doses of MOS on ruminal fermentation parameters in sheep.

\begin{tabular}{|c|c|c|c|c|c|c|}
\hline \multirow{2}{*}{ Items $^{1}$} & \multicolumn{4}{|l|}{ MOS $^{2}$} & \multirow{2}{*}{ SEM $^{3}$} & \multirow{2}{*}{$P$-value } \\
\hline & $0 \%$ & $0.8 \%$ & $1.6 \%$ & $2.4 \%$ & & \\
\hline \multicolumn{7}{|l|}{$\mathrm{SCFAs}^{4}$} \\
\hline Total, mM/L & 50.25 & 38.59 & 42.94 & 43.44 & 3.465 & 0.721 \\
\hline Acetate, $\%$ of total & 62.12 & 65.17 & 63.18 & 63.91 & 0.520 & 0.210 \\
\hline Propionate, $\%$ of total & 17.60 & 16.06 & 16.33 & 16.58 & 0.445 & 0.659 \\
\hline Butyrate, $\%$ of total & 13.49 & 11.96 & 14.38 & 13.51 & 0.687 & 0.683 \\
\hline Iso-butyrate, $\%$ of total & 1.923 & 2.200 & 1.870 & 1.859 & 0.137 & 0.816 \\
\hline Valerate, $\%$ of total & 1.318 & 1.189 & 1.139 & 1.152 & 0.066 & 0.789 \\
\hline Iso-valerate, $\%$ of total & 3.547 & 3.427 & 3.099 & 2.986 & 0.226 & 0.816 \\
\hline $\mathrm{C} 2 / \mathrm{C} 3^{5}$ & 3.595 & 4.072 & 3.911 & 3.997 & 0.121 & 0.550 \\
\hline Ammonia $\left(\mathrm{NH}_{3}-\mathrm{N}\right), \mathrm{mg} / 100 \mathrm{~mL}$ & $28.64^{\mathrm{a}}$ & $20.78^{\mathrm{ab}}$ & $19.79^{b}$ & $18.39^{\mathrm{b}}$ & 1.286 & 0.011 \\
\hline
\end{tabular}

$3{ }^{1}$ Sheep were fed $0,0.8,1.6$, or $2.4 \% \operatorname{MOS}(n=6$ per treatment). The mean of ruminal fermentation parameters results

4 are shown for each treatment after collection on the seventh day of the study.

$5 \quad{ }^{2} \mathrm{MOS}=$ mannan oligosaccharides

$6 \quad{ }^{3} \mathrm{SEM}=$ standard error of the mean

$7 \quad{ }^{4}$ SCFAs $=$ short-chain fatty acids

$8{ }^{5} \mathrm{C} 2 / \mathrm{C} 3=$ acetate/propionate

$9 \quad$ a,b Means within rows with different superscript letters significantly differ $(P<0.05)$.

10 


\section{Table 6(on next page)}

Effects of different doses of MOS on hematological parameters in sheep.

${ }^{1}$ Sheep were fed $0,0.8,1.6$, or $2.4 \% \operatorname{MOS}$ ( $n=6$ per treatment). The mean of hematological parameter results is shown for each treatment after collection on the seventh day of the study. ${ }^{2} \mathrm{MOS}=$ mannan oligosaccharides ${ }^{3} \mathrm{SEM}=$ standard error of the mean ${ }^{4} \mathrm{WBC}=$ white blood cell ${ }^{5} \mathrm{RBC}=$ red blood cell ${ }^{6} \mathrm{HGB}=$ hemoglobin concentration ${ }^{7} \mathrm{HCT}=$ hematocrit ${ }^{8}$ $\mathrm{MCV}=$ mean corpuscular volume ${ }^{9} \mathrm{MCH}=$ mean corpuscular hemoglobin ${ }^{10} \mathrm{MCHC}=$ mean corpuscular hemoglobin concentration ${ }^{11} \mathrm{RDW}=$ red blood cell distribution width ${ }^{12} \mathrm{PLT}=$ platelet counts ${ }^{13} \mathrm{MPV}=$ mean platelet volume ${ }^{14} \mathrm{PDW}=$ platelet distribution width ${ }^{15} \mathrm{PCT}=$ plateletcrit 
1 Table 6:

2 Effects of different doses of MOS on hematological parameters in sheep.

\begin{tabular}{|c|c|c|c|c|c|c|}
\hline \multirow{2}{*}{ Items $^{1}$} & \multicolumn{4}{|l|}{ MOS $^{2}$} & \multirow{2}{*}{ SEM $^{3}$} & \multirow{2}{*}{$P$-value } \\
\hline & $0 \%$ & $0.8 \%$ & $1.6 \%$ & $2.4 \%$ & & \\
\hline $\mathrm{WBC}^{4}, \times 10^{9} / \mathrm{L}$ & 190.4 & 206.4 & 189.4 & 183.4 & 7.136 & 0.730 \\
\hline $\mathrm{RBC}^{5}, \times 10^{12} / \mathrm{L}$ & 13.23 & 14.17 & 13.58 & 13.18 & 0.233 & 0.432 \\
\hline $\mathrm{HGB}^{6}, \mathrm{~g} / \mathrm{L}$ & 137.0 & 142.3 & 136.5 & 138.6 & 2.482 & 0.849 \\
\hline $\mathrm{HCT}^{7}, \%$ & 45.60 & 46.23 & 44.12 & 43.58 & 0.791 & 0.644 \\
\hline $\mathrm{MCV}^{8}, \mathrm{fL}$ & 34.58 & 32.68 & 32.57 & 33.10 & 0.380 & 0.200 \\
\hline $\mathrm{MCH}^{9}, \mathrm{pg}$ & 10.32 & 10.00 & 10.00 & 10.46 & 0.104 & 0.321 \\
\hline $\mathrm{MCHC}^{10}, \mathrm{~g} / \mathrm{L}$ & 299.8 & 307.5 & 309.0 & 317.4 & 2.339 & 0.068 \\
\hline $\mathrm{RDW}^{11}, \%$ & 15.00 & 15.45 & 15.28 & 15.14 & 0.168 & 0.820 \\
\hline $\mathrm{PLT}^{12}, \times 10^{9} / \mathrm{L}$ & 803.0 & 1074 & 902.5 & 749.0 & 65.68 & 0.337 \\
\hline $\mathrm{MPV}^{13}, \mathrm{fL}$ & 4.883 & 4.567 & 4.733 & 4.740 & 0.060 & 0.319 \\
\hline $\mathrm{PDW}^{14}$ & 16.10 & 15.82 & 15.83 & 16.02 & 0.057 & 0.202 \\
\hline $\mathrm{PCT}^{15}, \%$ & 0.391 & 0.430 & 0.423 & 0.351 & 0.025 & 0.713 \\
\hline
\end{tabular}

$3{ }^{1}$ Sheep were fed $0,0.8,1.6$, or $2.4 \% \operatorname{MOS}(n=6$ per treatment). The mean of hematological parameter results is

4 shown for each treatment after collection on the seventh day of the study.

$5 \quad 2 \mathrm{MOS}=$ mannan oligosaccharides

$6{ }^{3} \mathrm{SEM}=$ standard error of the mean

$7 \quad 4 \mathrm{WBC}=$ white blood cell

$8 \quad{ }^{5} \mathrm{RBC}=$ red blood cell

$9 \quad{ }^{6} \mathrm{HGB}=$ hemoglobin concentration

$10{ }^{7} \mathrm{HCT}=$ hematocrit

$11{ }^{8} \mathrm{MCV}=$ mean corpuscular volume

$12{ }^{9} \mathrm{MCH}=$ mean corpuscular hemoglobin

$13{ }^{10} \mathrm{MCHC}=$ mean corpuscular hemoglobin concentration

$14{ }^{11} \mathrm{RDW}=$ red blood cell distribution width

1512 PLT $=$ platelet counts

$16{ }^{13} \mathrm{MPV}=$ mean platelet volume

$17{ }^{14} \mathrm{PDW}=$ platelet distribution width

$18{ }^{15} \mathrm{PCT}=$ plateletcrit 
Figure 1

Schematic overview of the experimental program 


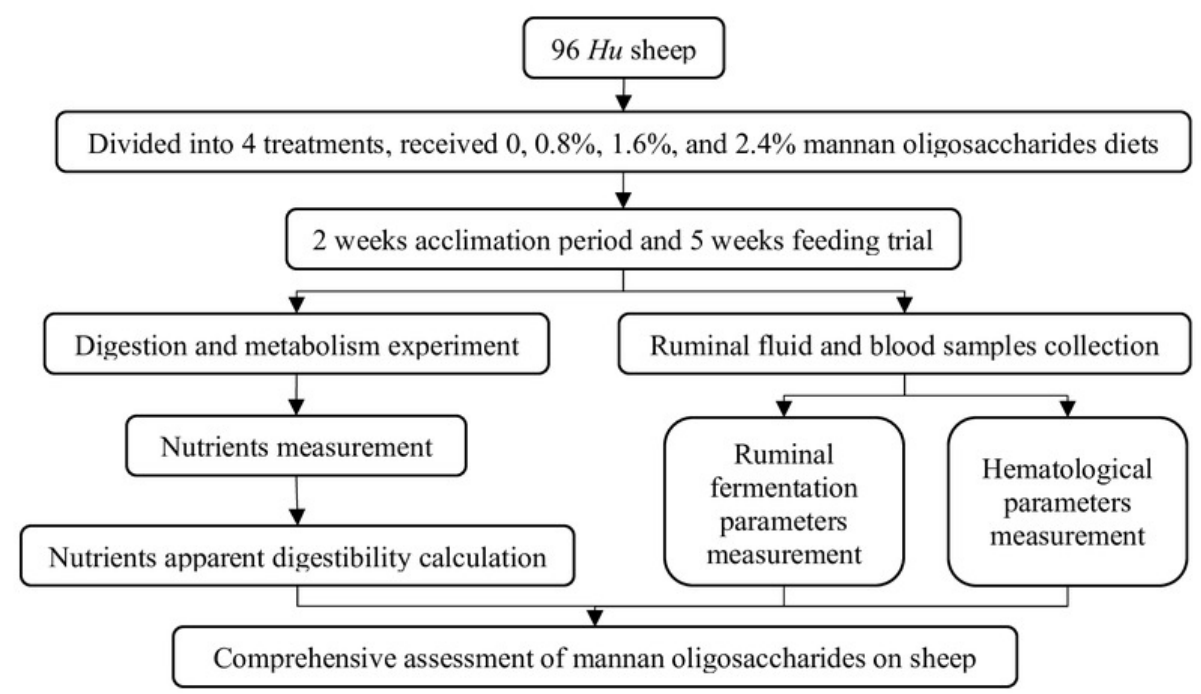

Figure 1 Schematic overview of the experimental program 